\title{
Research on the Human Rights Responsibility of MNEs
}

\author{
Yunhan Duan ${ }^{1, b, \dagger^{*}}$, Wenjin Jiang ${ }^{2, a, \dagger^{*}}$
}

\author{
${ }^{1}$ Southwest Minzu University \\ ${ }^{2}$ Student of Beijing University of Chemical Technology \\ *Corresponding author.Email: ${ }^{*} 2018070081 @$ mail.buct.edu.cn, ${ }^{b}$ lisilai1120@ gmail.com
}

${ }^{\dagger}$ These authors contributed equally.

\begin{abstract}
Multinational Enterprises (MNEs) play an increasingly important role in international society with the development of globalization. However, the problem of MNEs ignoring human rights protection to maximize their profits has become more and more serious in recent years. The paper will analyze the relationship between MNEs and human rights protection from the cases of the violation of personal rights such as the right to life and health, the legitimate rights of employees, the right to privacy, and so on. It can be seen that MNEs have neglected human rights protection and the lack of human rights protection methods of existing regulations. Based on these, the responsibility of human rights protection of MNEs can be improved from external regulation and internal regulation. Including these, external regulations are double protected by international law and domestic law. The internal regulation is mainly based on the MNEs to improve their conduct.
\end{abstract}

Keywords: Multinational Enterprises, human rights protection, right to life and health, labor rights, right to privacy.

\section{THE RAISING OF THE QUESTION}

With the development of economic globalization, MNEs play an increasingly important role in the international community. On the one hand, the global expansion of MNEs complies with the trend of economic globalization. On the other hand, the development of MNEs has promoted the flow of capital and other factors of production in the world. However, in recent years, MNEs have to maximize the benefits, and neglect the issue of human rights protection has become the focus of international social disputes.

Human rights as a concept that can indicate social relationships, the United Nations is defined by it, "Human rights are the inherent right of all human beings, without regard to race, sex, national origin, ethnic origin, language, religion or any other status. Human rights include the right to life and liberty, the right to freedom from slavery and torture, the right to freedom of opinion and expression, the right to work and education, and much more, and everyone is entitled to the enjoyment of these rights without discrimination [1]." The United Nations Multinational Corporate Corporation was defined in the "Draft of the
Multinational Corporation Code of Corporation" in 1977 to 1986 . A multinational company is defined as a public or a public-private company. Regardless of its legal form and activity scope, such enterprises' entities need to be distributed in two or more countries. Each entity passes one or several decision-making centers, carrying out business activities under a decision system, with a common strategy and consistent policies. Each Entity interconnects entity due to ownership relationships or other factors [2]. Although MNEs have appeared as a special enterprise organization, it is a corporation aggregate whose core is to make profits, given that many human rights issues had aroused inevitably in its pursuit of maximizing profits. The support logic of "benefit maximization", MNEs are more diverse in their forms of human rights violations [3]. For example, Union Carbide has caused a cyanide leak at a pesticide plant set up by its Indian subsidiary near the slum of Bhopal City, which infringed the right to residents and caused huge pollution on the local environment [4]. In addition, the incidents of MNEs violate labor rights by MNEs are not uncommon. For example, most products from Apple are derived from Foxconn, which is known as a "Sweatshop" [5]. What is more, in the HM boycott in the Xinjiang cotton incident 
[6], HM utilizes public opinion to infringe the fundamental rights of Xinjiang labor. All of the above incidents point to the infringement of human rights by MNEs, which shows that MNEs still have many problems in human rights protection. Therefore, this paper takes a typical incident of MNEs to violate human rights, combing the internal regulation and external regulation of human rights, and proposes improvement for the existing human rights protection.

\section{SPECIFIC MANIFESTATIONS OF HUMAN RIGHTS VIOLATIONS BY MNES}

\subsection{Violations of the right to life and health}

In 1984, a cyanide spill at a pesticide plant set up by the India subsidiary of Union Carbide near a slum in Bhopal city killed more than 20000 people directly and more than 55000 indirectly. More than 200000 people were permanently disabled. Even the nearby livestock was not spared. In this incident, much evidence shows that the accident's root cause is Union Carbide's blind pursuit of economic interests and ignoring human rights protection. At the same time, this incident is also the best case of developed countries transferring high pollution and high-risk enterprises to developing countries. MNEs are willing to transfer their subsidiaries to developing countries because the environmental standard of developing countries is relatively low. To attract foreign investment and introduce advanced technology and equipment to develop their economies, developing countries often reduce security and environmental protection standards. The strict requirements of environmental protection in developed countries also force MNEs to transfer industries with low technical content, great harmful to the safety and environment to developing countries, which leads to the international trend of "Industry Transfer" . For example, one of the most important reasons for the fire incident at Zhili toy factory owned by Hong Kong Enterprises in Shenzhen, Guangdong Province in 1993, was that the local government, to retain foreign investment, did not dare to take strict demands on the management of production safety. The supervision and inspection were not in place, and even bribed the fire safety rectification team to create a socalled loose environment for foreign investment.

The huge gap of environmental standards between developing countries and developed countries has enabled the legal regulation of MNEs behavior in developing countries, which results in MNEs ignoring human rights protection to maximize production efficiency. In the above incidents, the behavior of MNEs has caused huge pollution to the host country and seriously endangered the right of residents.

\subsection{Violations of labors rights}

Foxconn is a typical representative of the "Sweatshops", who exploit and violate labors' rights to maximize production efficiency. As the world's largest original equipment manufacturer, Foxconn's company is located in many provinces of China. Its factory in Hengyang, China, is the supplier of Amazon Echo speakers and e-book readers production equipment. This factory employed many interns under the age of 16 , and the wage standard was far below the minimum requirement set by the Labor Law of the People's Republic of China, and regular overtime became normality. According to Articles 15 [7] and 36 [8] of the Labor Law, firstly, factories are not allowed to employ minors under the age of 16; Secondly, employees should not work more than 8 hours a day and 44 hours a week average. If an extra word needs to be done, the factory should pay more for overtime costs. The Foxconn Hengyang factory infringes on laborers' fundamental rights, which essentially reflects MNEs' failure to take their human rights responsibilities.

In March 2021, HM stated that forced labor existed in the cotton-producing areas in Xinjiang, China, followed by the utilization of public opinion to maliciously slander and wantonly plant Xinjiang cotton. That leads many international brands in BCI to stand in the wrong line, and launched a joint boycott of Xinjiang cotton.

The statement resisted the cooperation with Xinjiang garment manufacturing enterprises and prohibited the purchase of local products or raw materials. This statement is not only groundless but also seriously infringes on the legitimate rights of Chinese laborers. As the cotton production in Xinjiang strictly abides by the Labor Law of the People's Republic of China, Xinjiang has already achieved mechanization of large-scale cotton picking in 2018. In this incident, HM's violation of human rights in China is the utilization of malicious planting to cause a serious imbalance in the cotton market in Xinjiang, resulting in an impact on the entire industry chain. Finally, it infringes the legitimate rights of cotton factory workers and upstream textile mill workers in Xinjiang. As John G. Ruggie [9], the special representative of the Secretary General of the United Nations, said in his report, the behavior of companies has an impact on human rights. The affected labor rights include freedom of association, the right to nondiscrimination, the right to a safe working environment, and so on. HM's behavior is utilizing the labor rights issue to boycott Xinjiang cotton on the surface. Still, it is to infringe the legitimate rights of Chinese workers and even to interfere in China's internal affairs by utilizing the issue of labor rights protection. 


\subsection{Violations of rights to privacy}

There is no doubt that the Internet is the major pushing factor for the development of information globalization. The "information era" makes it possible for human beings to transfer and share information rapidly, which promotes the flourish of the social media industry. In 2020, the Australian privacy Regulatory Agency filed a lawsuit against social media giant-Facebook accused it of sharing more than 300000 users' personal information with Political Advisor Cambridge Analysis Company in the unauthorized. The Australian Information Commissioner (OAIC) office points out in the lawsuit filed by the Federal Court. Facebook infringed the privacy law by stealing users' information for political analysis through an investigation product on its website called "this is your digital life". In July of the same year, Facebook was also accused of improperly sharing 87000000 users' information worldwide by using the investigative tools of Cambridge Analytica, a consulting firm whose clients include US President Donald Trump's 2016 campaign. Finally, Facebook was fined a record 5 billion dollars by the Federal Trade Commission in the US. In the above incidents, users' rights to privacy have been violated. The right to privacy is an important part of human rights, and it is double protected by international law and domestic law. MNEs control an enormous amount of users' information. They should pay more attention to the protection of the users' rights to privacy. The obligation to respect requires MNEs should pay attention to avoid collusion, non-intervention, do not violate mandatory regulations. They also should not avoid legal and human rights requirements.

\section{THE PATHS AND PROBLEMS OF MNES' HUMAN RIGHTS RESPONSIBILITY}

The paths to regulate the human rights responsibility of MNE are currently divided into external intervention and internal intervention. External intervention includes the use of international regulations and domestic rules to regulate. Internal intervention mainly refers to the selfrestraint and self-regulation of MNEs. It should be noted that both external and internal intervention require MNEs to assume the responsibility of preventing human rights violations and the responsibility of remedying violations. We have admitted that both of them have some problems to be solved.

\subsection{Paths of external interventions and existing problems}

\subsubsection{International law and problems}

There are two main methods to use the international law-making MNEs to take the human rights responsibility: "hard law" and "soft law". Hard law mainly includes customary international custom, international treaties, etc., which are legal documents with strong legally binding. For example, the United Nations has promulgated a series of international conventions related to protecting the human rights of MNEs. However, these conventions are only effective for contracting states and therefore have a limited scope. Although soft law does not have the mandatory force in the sense of international law, it has still played an important role in guiding the MNEs to undertake the human rights responsibilities in recent years. For example, the discussions on the human rights responsibilities of MNEs have been included in the draft code of conduct for transnational corporations, which was negotiated by the United Nations in 1977 [10]. Although the draft did not reach an agreement due to the different demands of the different international communities, it, to a large extent, promoted the study of the human rights responsibilities of MNEs. It also makes more MNEs aware of the importance of human rights protection. However, due to the weak legal binding force of soft international law and often in the form of fragmentation, such as the international declaration, guide, and so on, soft international law has unclear provisions and lack of operability. To sum up, "hard law" and "soft law" both have some shortcomings in solving the problem of human rights protection.

\subsubsection{Domestic rules and problems}

The domestic legal system refers mainly to the laws of the host country and the home country. As far as the host country is concerned, most of them set up the general censorship system, national security censorship system, etc. Therefore, at the beginning of the MNEs entry, they must strictly abide by the rules and regulations of the host country [11]. And the host country has absolute jurisdiction over the human rights violations committed by MNEs according to the sovereignty principle granted by international law. Once a transnational corporation has the behaviors of human rights violations, the host country can use the relevant rules to punish their behaviors.

If the host country has perfect and effective legislation and a law-enforcement system, the human rights responsibilities of MNEs can be effectively regulated. For example, the existing three types of foreign-funded enterprises' law in China and the Catalogue of Industries for Guiding Foreign Investment contain specific measures to protect human rights [12]. Meanwhile, the Institute of Social Development Strategy and the Chinese Academy of Social Sciences began publishing the Blue Paper on Corporate Social Responsibility in 2009 to urge MNEs in China to assume their human rights responsibilities [13]. It can be seen that the Chinese government set up strict 
censorship on the entry of MNEs, but not all host countries have strict censorship when the transnational corporations come into their markets. Nevertheless, some governments eager to bring rapid economic growth through MNEs are willing to create a "Loose" investment environment for foreign investors to absorb capital and technology. These governments put their economic development ahead of human rights protection. Some countries do not have corresponding rules and regulations, which leads to the ineffective regulation of MNEs' human rights violations.

As far as the home country is concerned, it has the right to regulate the overseas activities of transnational corporations according to its rules of nationality jurisdiction and territorial jurisdiction regulated by international law. If a transnational corporation commits human rights violations in the host country, its home country can also regulate it by using its laws to protect human rights. However, this kind of regulation in the home country is useless in practice. On the one hand, the home country has a higher judicial cost to regulate the human rights responsibility of MNEs; on the other hand, the home country tends to give special protection to their transnational corporations for its interests.

\subsection{Paths of internal interventions and problems}

In addition to the paths of external interventions, the internal self-regulation of MNEs is also very important. As the subject to undertake the human rights responsibility, MNEs should establish the idea of respecting human rights, implement relevant human rights decisions, and encourage their employees to actively pursue their legitimate interests. Only in this way can MNEs reduce their human rights violations and assume their human rights responsibilities [14].

\subsubsection{Internal codes of conduct on MNEs}

MNEs generally establish their internal codes of conduct based on Codes of Conduct established by industry or consumer organizations. Regarding human rights responsibilities, MNEs generally require that their own companies, subsidiaries, suppliers, contractors, etc., comply with certain labor and environmental standards [15]. For instance, NIKE CORPORATION requires in its Code of Conduct that "contractors respect the rights of all employees in their management practices, including their rights to freedom of association and collective bargaining. Contractors must respect the dignity of every employee and their right to a working environment that is free from harassment, abuse, or corporal punishment. No person may be discriminated against based on race, belief, gender, marriage, age or gender orientation, ect[16]. " Most of these transnational corporations develop codes of conduct that constrain their behavior, through internal self-regulation to reduce the occurrence of human rights violations, especially to reduce the violation of the rights and interests of workers.

\subsubsection{Provisions relating to the protection of the employees}

When multinational companies draw up codes of conduct, most of them will draw up additional provisions to protect employees' rights and interests. Such as encourage employees to actively participate in the company's code of conduct. Take the Huawei Supplier Social Responsibility Code of conduct as an example. The code has five components: labor rights, health and safety, environmental protection, business ethics, and management systems [17]. Among them, the provisions of labor rights and interests as the priority content of the code of conduct refine and emphasize the employees' free choice of employment, working hours, and salary treatment based on the existing laws and regulations in China. According to this, we can find that the MNEs embody the human rights responsibility by protecting their employees' legal rights and interests.

\subsubsection{Existing problems}

MNEs do take on some human rights responsibilities through their internal codes of conduct. Still, because of the profit-seeking nature of capital, the fulfilment of human rights obligations often gives way to the pursuit of profit maximization, which leads to the appearance of human rights violations.

In the case of internal codes of conduct, it is difficult to measure the degree of implementation of internal codes of conduct. However, this reflects the social responsibility of the enterprise. For employees, the MNEs do not give them enough ways to exercise their voice when these companies draw up the code of conduct. The development of codes of conduct is inherently skewed in the protection of MNEs. In addition, after employees' legitimate rights and interests are violated, they are often unwilling to seek a remedy through trade unions or court because of the pressure from many sides.

\section{SOLUTIONS AND SUGGESTIONS}

\subsection{Improvement of external interventions}

\subsubsection{About international law}

With economic globalization and international law development, the boundary between "Hard law" and "Soft Law" is increasingly blurred. "Soft law gradually becomes hard law" has become the main trend of the future development of international law. In summary, 
the "soft law" and "hard law" in the international community should complement and learn from each other to better control and guide the MNEs. From the perspective of globalization, the regulation of the human rights responsibility of MNEs is no longer a "separate version" solution. Only by giving full play to the respective advantages of "soft law" and "hard law", and combining the laws and regulations of the host country and the home country can we better regulate the human rights responsibilities of MNEs [18].

\subsubsection{About domestic law}

As far as the host country is concerned, in addition to improving the laws and regulations and improving its judicial efficiency, it also needs to pay special attention to the review of MNEs before entering the domestic market. In other words, the host country's government needs to make a pre-assessment of the human rights risks that the production and operation of MNEs may cause in the host market in the future. For example, after China acceded to the WTO, it has introduced many foreign capitals. Still, it has not conducted a full investigation on the human rights risks of these multinational companies that have poured into the domestic market in a short period. As a result, the basic human rights of Chinese workers cannot be fully protected and even seriously violated. In particular, environmental pollution caused by some MNEs is a serious threat to citizens' right to life and health. Therefore, the host country must establish and improve the foreign investment review system. By improving the review system, MNEs can better bear the responsibility of human rights, and the host country can better regulate the behavior of MNEs.

As far as the home country is concerned, the legislature of the home country needs to improve its existing laws and regulations, especially laws on the human rights protection obligations of MNEs, and introduce specific regulatory measures. Secondly, the home country's government needs to recognize the importance of human rights protection and the international significance of regulating the behavior of MNEs. Finally, the home country needs to give full play to its principle of nationality jurisdiction and territorial jurisdiction to regulate the human rights violations of MNEs timely and effective. Based on the above methods, the home country can also require the MNEs to evaluate the human rights issue of the host country before they invest. Through the human rights assessment report, we can check whether there are human rights risks in the host country, what kind of human rights risks exist and how to deal with them [19]. Through this requirement, the home country can better introduce preventive measures to guide the behavior of MNEs in other countries.
In addition, due to the different standards of human rights protection in different countries, the human rights responsibilities of transnational corporations after entering the market of different countries are not the same. Therefore, we argue that the human rights obligations of MNEs can be established through the internalization of domestic standards and domestic internationalization standards. In other words, the host country and the home country jointly formulate international human rights rules and unify the standards of human rights responsibilities of MNEs by joining international conventions. As for China, an investment market with great potential, it should actively join the international conventions to implement the internationalization of domestic standards and enhance the right to speak to better solve the issue of human rights responsibilities of MNEs.

\subsection{Improvement of the internal interventions}

From the Bhopal gas leak in India to Foxconn's "sweatshop", a series of incidents have made the brand image of these well-known multinational companies plummet and has also affected the further development of these companies to a certain extent. Therefore, multinational companies must formulate a "code of conduct" in line with the long-term development concept of the company. The code of conduct should include the development direction of transnational corporations and contain the concept of human rights protection. Besides, MNEs should constantly adjust and simplify their codes of conduct in their development, expanding the content of the protection of employees' rights and interests. Among them, streamlining the code of conduct can make the employees more intuitive and convenient to understand the provisions relating to their rights, knowing the way of remedy.

However, in addition to their internal codes of conduct, MNEs should develop a sense of selfresponsibility. In other words, MNEs should emphasize the importance of social responsibility in the process of forming their corporate culture. In practice, the values of corporate social responsibility and human rights protection can be transmitted through staff training, which can make employees have a stronger awareness of rights protection and constantly monitor the undertaking human rights responsibilities of MNEs. Only when the enterprise has formed the overall awareness of taking social responsibility can the enterprise better abide by its internal code of conduct and realize the long-term development to gain the maximum benefit of the enterprise through selfregulation and self-restraint.

What's more, employees of MNEs should also actively fight for their legitimate rights to promote the undertaking of human rights responsibilities of MNEs. For example, workers can fight for more rights for 
themselves by establishing trade unions and expanding the influence of their voice. When MNEs have infringed upon the legitimate rights of workers, trade unions should negotiate with MNEs to force them to assume their human rights responsibilities. All in all, employees can actively seek protection through a series of ways, and supervise the behavior of MNEs, so that MNEs would like to pay more attention to the demands of employees and take the initiative to assume human rights responsibilities.

\section{CONCLUSION}

In the development trend of economic globalization, the flow of capital and labor is gradually accelerating. For multinational companies, this is a great opportunity to spread capital all over the world. However, the issue of international human rights protection is a new challenge. Under the guidance of the profit maximization of transnational corporations, the basic human rights of vulnerable groups have been repeatedly violated, and legal working conditions and working hours have been ignored. The international community has also become increasingly vocal about protecting human rights by MNEs, while the regulation of human rights violations has also become diversified and multilevel. From the international level, the international subject status of MNEs has been gradually recognized. In a word, any rights and obligations should be peers. When you enjoy a certain extent of rights, you also need to bear corresponding obligations. This suggests that MNEs should bear responsibilities and human rights responsibilities. From the social level, the enterprise is the product of the society, and its pursuit of maximum interests is based on the social resources it possesses. Therefore, MNEs have an obligation to assume the corresponding responsibility to protect the interests of stakeholders.

\section{REFERENCES}

[1] "Human Right".

DOI: https://www.un.org/zh/sections/issuesdepth/human-rights/index.html.

[2] "Draft United Nations Code Of Conduct On Transnational Corporations". DOI: https://digitallibrary.un.org/record/102937?ln=en

[3] Zhao Lanyin, Chen Lei, Theoretical Proof and Empirical Study of Human Rights Obligation of Transnational Corporations, in: Commercial World, 2012(12), pp:102, DOI: 10.3969/j.issn.1002-5863.2012.12.044

[4] "India Bhopal gas leak case". DOI: https://www.worldatlas.com/articles/the-bhopalgas-leak-disaster.html.
[5] "Sweatshop". DOI: https://www.britannica.com/topic/sweatshop.

[6] "China Cotton Industry Alliance". DOI: https://mp.weixin.qq.com/s/qwdu_YZB3qJx8Fgv0 qbF3A, last visit on April 22,2021

[7] "Labor Law of the People's Republic of China". DOI:

http://www.npc.gov.cn/npc/c30834/201901/ffad2d 4ae4da4585a041abf66e74753c.shtml

[8] "Labor Law of the People's Republic of China". DOI:

http://www.npc.gov.cn/npc/c30834/201901/ffad2d 4ae4da4585a041abf66e74753c.shtml

[9] "United Nations Guiding Principles on Business and Human rights". DOI : https://en.m.wikipedia.org/wiki/United_Nations_G uiding_Principles_on_Business_and_Human_Righ ts.

[10] Ma Zhongfa, Zhao Sihan, International system governance of multinational corporations' operation from the perspective of the United Nations, in: Yang Weidong (Eds.), Jianghan academic journal, 2021, 40(03), pp. 95-107. DOI: 10.16388/j.cnki.cn42-1843/c.2021.03.009

[11] Yu Jinsong, International economic law (Second Edition), higher education press, 2019.

[12] Three types of foreign-funded enterprises' law in China includes the law of the people's Republic of China on Chinese foreign equity joint ventures, the law of the people's Republic of China on Chinese foreign contractual joint ventures, and the law of the people's Republic of China on foreign funded enterprises. The Catalogue of Industries for Guiding Foreign Investment was revised in 2017 andcame into effect on July 28, 2017.

[13] Shao min, Bao Qun, The impact of FDI on domestic labor rights and interests in China: improvement or deterioration, Managing the world, September 2013(09), pp. 32-43. DOI: 10.19744/j.cnki.11-1235/f.2013.09.005

[14] Han Xiuli, Research on environmental protection of China's overseas investment from the perspective of international investment law, Law Press, 2013.

[15] Zhou Changzheng, code of conduct for multinational companies and Chinese labor standards, international law review of Wuhan University, 2003, 1(00), pp. 269-287. DOI: 10.13871/b.cnki.whuilr.2003.00.017 
[16] Sarah Anderson, John Cavanagh, Top 200: The Rise of Corporate Global Power, Institute for Policy Studies, 2000. p.1-5. DOI: http://www.laputan.org/pub/books/Top_200.pdf

[17] "Huawei supplier social responsibility code of conduct". DOI: https://www.huawei.com/cn/sustainability/winwin-development/develop_Supplychain / Huawei supplier social responsibility code of conduct.

[18] Ma Zhongfa, Zhao Sihan, International system governance of multinational corporations' operation from the perspective of the United Nations, Jianghan academic journal, 2021, 40(03), pp. $\quad 95-107$. DOI: 10.16388/j.cnki.cn421843/c.2021.03.009

[19] Wang Han, A.A. (2017). Research on the home country regulation path of human rights violations by transnational corporations, in Unpublished masteral dissertation. Xiamen University, Fujiang. 